\title{
An Incubation Experiment to Study Potassium Fractions using Azolla, Vermicompost and Muriate of Potash as Potassium Sources in Inceptisol of Bihar
}

\author{
Mukta Rani ${ }^{1 *}$, Arun Kumar Jha ${ }^{2}$, Bipin Bihari², Amarjeet Kumar ${ }^{2}$ and Ajeet Kumar \\ ${ }^{1}$ Department of Soil Sc. \& Agril. Chemistry, Institute of Agriculture Sciences, \\ Banaras Hindu University, Varanasi-221005, India \\ ${ }^{2}$ Department of Soil Sc. \& Agril. Chemistry, Bihar Agricultural University, \\ Sabour, Bhagalpur-813210, India \\ *Corresponding author
}

\section{A B S T R A C T}

\begin{tabular}{|c|}
\hline Keywords \\
\hline $\begin{array}{l}\text { Azolla, Water- } \\
\text { soluble K, } \\
\text { Exchangeable K, } \\
\text { Non-exchangeable } \\
\text { K, DAI }\end{array}$ \\
\hline Article Info \\
\hline $\begin{array}{l}\text { Accepted: } \\
18 \text { April } 2020 \\
\text { Available Online: } \\
10 \text { May } 2020\end{array}$ \\
\hline
\end{tabular}

To explore the suitability of various sources of potassium $(\mathrm{K})$ application on $\mathrm{K}$ fractions (watersoluble $\mathrm{K}$, Exchangeable $\mathrm{K}, 1 \mathrm{~N} \mathrm{HNO}_{3}$ soluble $\mathrm{K}$, Non-exchangeable K) through incubation study. An incubation experiment was conducted at department of soil science and agricultural chemistry, Bihar Agricultural University, Sabour, Bhagalpur in completely randomized block design with 8 treatments viz., $\mathrm{T}_{1}$ (no $\mathrm{K}$ application), $\mathrm{T}_{2}$ (50 per cent RDK), $\mathrm{T}_{3}(100$ per cent $\mathrm{RDK}), \mathrm{T}_{4}$ (150 per cent RDK $), \mathrm{T}_{5}(50$ per cent RDK +50 per cent $\mathrm{K}$ by Azolla $), \mathrm{T}_{6}(50$ per cent $\mathrm{RDK}+50$ per cent $\mathrm{K}$ by vermicompost), $\mathrm{T}_{7}$ (100 per cent $\mathrm{K}$ by Azolla) and $\mathrm{T}_{8}$ (100 per cent $\mathrm{K}$ by vermicompost) replicated thrice and kept in incubator at $25 \mathrm{deg}$. Celsius and used to assess various forms of $\mathrm{K}$ in soil at $0,35,70$ and 105 days of incubation. Full dose of $\mathrm{N}$ and $\mathrm{P}$ were applied in all the treatments through urea and SSP respectively. However, potassium was supplied through muriate of potash (MOP ; 60 per cent $\mathrm{K}_{2} \mathrm{O}$ ), vermicompost ( 0.8 per cent $\mathrm{K}$ ) and Azolla ( 2.62 per cent $\mathrm{K}$ on dry wt. basis). Experiment showed that available $\mathrm{K}$ content of incubated soil increases from 0 to 35 days of incubation (DAI) and decreases thereafter up to 105 DAI. Decrease in available K from 90 to 105 DAI was $13.87 \%$ in $\mathrm{T}_{3}$. However, this decrease was only $3.97 \%$ and $1.5 \%$ in the treatment $\mathrm{T}_{5}$ and $\mathrm{T}_{6}$ respectively. Azolla and vermicompost maintains $\mathrm{K}$ availability by increasing exchangeable $\mathrm{K}$ and ensures constant availability of potassium.

\section{Introduction}

The fertility status of Indian soils has been declining continuously due to intensive cropping and non-restoration of nutrients in the soil. The replenishment of reserves of nutrients are necessary which are removed or lost from the soil for maintaining productivity and sustainability of the farming systems (Peoples et al., 1995). Deficiency of major nutrients especially nitrogen (N) and potassium $(\mathrm{K})$ is prevailing in the Indian soils resulting in sharp decline in production and productivity of nutrient responsive crops. Potassium is one of the most important essential major plant nutrients, which is 
required by the plants in large amount and is available to the plants in cationic form $\left(\mathrm{K}^{+}\right)$. $\mathrm{K}$ is required for photosynthesis, fruit formation, osmotic regulations, disease resistance, promotion of enzymes activity, translocation of assimilates and underpinning agronomic productivity and sustainability (Mengel, 1985). Suboptimal application rates of $\mathrm{K}$ fertilizers and manures in India have lead to depletion of $\mathrm{K}$ stocks in soil resources (Srinivasarao et al., 2014). Hence, it is required to apply potassium at recommended dose for successful crop cultivation. But, the destitute condition of the Indian farmers may not allow them to put the $\mathrm{K}$ optimally in the soil owing to high cost of imported fertilizers. Also, the continuous and liberal use of potassic fertilizer alone through fertilizers affects soil productivity and thus results in lower yield with poor quality of produce. Thus, there is a need to search suitability of Azolla and vermicompost as $\mathrm{K}$ source and its effect on soil K. Use of Azolla, vermicompost, farmyard manure (FYM) can serve as healthy and economical sources of potassium. Out of the potential sources of potassium, Azolla has its own significance due to higher biomass production rate, fair $\mathrm{K}$ content and suitability for kharif crops. The judicious combinations of organic and inorganic sources of plant nutrients are essential not only to maintain the soil health but also to sustain productivity of the crops.

The study of availability of different forms of potassium is important while studying the response of crops to K. Availability of soil K to plant is controlled by dynamic interactions among its different chemical forms (Wang et al., 2004). The components of dynamic interactions are water soluble $\mathrm{K}$, which is taken up directly by plant; exchangeable K, held by negatively charged sites of clay particles; non-exchangeable $\mathrm{K}$, which is trapped between layers of expanding lattice clays; and total $\mathrm{K}$.

\section{Materials and Methods}

An incubation study was conducted at the department of soil science and agricultural chemistry of Bihar Agricultural University, Sabour for determining the different fractions of potassium at $0,35,70,105$ days of incubation (DAI). The soil sample used for the incubation study was collected from the field experimental site at $0-15 \mathrm{~cm}$ depth prior to sowing of the crop. It was finely ground and sieved with $2 \mathrm{~mm}$ sieve for incubation studies. The water holding capacity of soil was determined by Keen's cup method given by Keen-Razkowski (1921). In incubation studies three replicates of $21 \mathrm{gm}$ soil samples were taken in plastic bottles and treatments were given in Completely Randomized Design with ttreatments viz., $\mathrm{T}_{1}$ (no $\mathrm{K}$ application), $\mathrm{T}_{2}$ (50 per cent recommended ose of potassium i.e. RDK), $\mathrm{T}_{3}$ (100 per cent RDK), $\mathrm{T}_{4}$ (150 per cent RDK), $\mathrm{T}_{5}$ (50 per cent $\mathrm{RDK}+50$ per cent $\mathrm{K}$ by Azolla), $\mathrm{T}_{6}$ (50 per cent $\mathrm{RDK}+50$ per cent $\mathrm{K}$ by vermicompost), $\mathrm{T}_{7}$ (100 per cent $\mathrm{K}$ by Azolla) and $\mathrm{T}_{8}(100$ per cent $\mathrm{K}$ by vermicompost) replicated thrice. Azolla and vermicompost used as source of $\mathrm{K}$ consisting $2.6 \%$ (on dry wt. basis) and $0.8 \%$ total $\mathrm{K}$ respectively. Uniform dose of nitrogen and phosphorus@ 100 and $60 \mathrm{~kg} \mathrm{ha}^{-1}$ through urea and SSP respectively was applied to all the treatments. Distilled water was added to maintain the moisture at field capacity (60 per cent of the water holding capacity). The samples were incubated at $25^{\circ} \mathrm{C}$ for $0,35,70$, 105 days ( 8 treatments $\times 3$ replications $\times 4$ periods). At the end of each incubation period, the three replicates for each treatment were removed from the incubator. The samples were air dried and analyzed for different forms of potassium. Water soluble $\mathrm{K}$ was extracted by shaking the soil with distilled water in the ratio 1: 5 for one hour and estimated flame photometrically (Hanway and Heidel, 1952). Available K was extracted by shaking the soil with $1 \mathrm{~N}$ neutral 
ammonium acetate in soil solution ratio of 1 : 5 for 5 minutes and estimated flame photometrically (Hanway and Heidel, 1952). Exchangeable potassium was obtained by subtracting the water soluble $\mathrm{K}$ from available $\mathrm{K}$ (Hanway and Heidel, 1952). 1N nitric acid $\left(\mathrm{HNO}_{3}\right)$ soluble potassium was extracted with boiling $1 \mathrm{~N}^{\mathrm{HNO}_{3}}$ for 10 minutes in soil solution ratio of 1: 2.5 and estimated flame photometrically (Wood and DeTurk, 1940). Non-exchangeable potassium was subtracted from $1 \mathrm{~N} \mathrm{HNO}_{3}$ potassium to get nonexchangeable potassium. All results of Kfractions were estimated in $\mathrm{mg} \mathrm{kg}^{-1}$. The water holding capacity of intial soil samples was 55 per cent. The different potassium forms of intial soil samples were also analysed. Water soluble-K, Exchangeable-K, Available-K, $1 \mathrm{~N} \quad \mathrm{HNO}_{3}-\mathrm{K}$ and nonexchangeable potassium value of intial soil samples were $21.9,57.71,79.61,388.1$ and $308.5 \mathrm{mg} \mathrm{kg}^{-1}$ respectively.

\section{Results and Discussion}

\section{Water soluble potassium}

Result showed that at all days of incubation, water soluble $\mathrm{K}$ was higher in potassium treated soil than control. The water soluble $\mathrm{K}$ was lowest and remained almost constant at all days of incubation in control treatment. Whereas, at 35 days of incubation, all the potassium treated soil showed marked increase in water soluble potassium. The increase in water soluble $\mathrm{K}$ was the highest in $\mathrm{T}_{4}$ (150 per cent RDK) followed by $\mathrm{T}_{3}(100$ per cent RDK), $\mathrm{T}_{5}$ (50 per cent RDK +50 per cent $\mathrm{K}$ by Azolla), $\mathrm{T}_{6}(50$ per cent $\mathrm{RDK}+50$ per cent $\mathrm{K}$ by vermicompost), $\mathrm{T}_{7}$ (100 per cent $\mathrm{K}$ by Azolla), $\mathrm{T}_{2}$ (50 per cent RDK) and $\mathrm{T}_{8}$ (100 per cent $\mathrm{K}$ by vermicompost). At 70 and 105 days of incubation, $\mathrm{T}_{2}$ (50 per cent RDK), $T_{3}$ (100 per cent RDK) and $T_{4}(150$ per cent RDK) shows marked reduction in water soluble $\mathrm{K}$.
The treatment with integrated $\mathrm{K}$ application or K application by Azolla or VC also showed the decreasing trend of water soluble $\mathrm{K}$ at 70 and 105 days of incubation, but the magnitude of decrease was less and maintained a considerable amount of water soluble $\mathrm{K}$. The decrease in water soluble $\mathrm{K}$ from 70 to 105 days of incubation in $\mathrm{T}_{3}$ (100 per cent RDK) was 19.25 per cent while only 10.66 and 7.59 per cent in treatment $\mathrm{T}_{5}(50$ per cent $\mathrm{RDK}+$ 50 per cent $\mathrm{K}$ by Azolla) and $\mathrm{T}_{6}(50$ per cent RDK +50 per cent $\mathrm{K}$ by vermicompost) respectively (Fig. 1).

The higher amount of water soluble $\mathrm{K}$ in MOP treated soil at 0 days of incubation is attributed to the presence of water soluble potassium content in fertilizers. It is clear from the results that, treatment with organic material alone or in combination with organic material and fertilizers releases $\mathrm{K}$ after a period of time owing to decomposition of organic material and maintaining water soluble $\mathrm{K}$ content of soil, which is readily available for plant. Organic material during their decomposition produces large amount of organic acids which might have tendency to dissolve potassium present either in mineral form or in the non-exchangeable form, thereby bringing it into water soluble form.

As the decomposition of Azolla is faster than vermicompost owing to more nitrogen content in Azolla, thus releases more water soluble $\mathrm{K}$ at 35 days of incubation in comparison to vermicompost. The result was in accordance with findings of Kaur and Benipal (2006) and Venkateswarlu et al., (2014).

\section{Exchangeable potassium}

Data obtained from 0 to 35 days of incubation showed that exchangeable $\mathrm{K}$ had a increasing trend in all the treatments, except control. After 35 days of incubation, MOP- K treated soil showed only slight increase in 
exchangeable $\mathrm{K}$ up to 70 days of incubation and then decreases thereafter up to 105 days of incubation. Whereas, treatment receiving $\mathrm{K}$ from Azolla or VC in addition to fertilizer- K, showed increasing trend at both 70 and 105 days of incubation. Treatment receiving $\mathrm{K}$ from either only Azolla or VC recorded the highest increase in exchangeable $\mathrm{K}$ up to 105 days of incubation. $\mathrm{T}_{7}$ (100 per cent $\mathrm{K}$ by Azolla) recorded the highest increase in exchangeable $\mathrm{K}$ which was 50.91 per cent from 0 to 35 days of incubation while, 3.31 and 4.05 per cent from 35 to 70 and 70 to 105 days of incubation respectively.

The highest increase in exchangeable $\mathrm{K}$ in treatment $\mathrm{T}_{7}$ (100 per cent $\mathrm{K}$ by Azolla) was followed by $\mathrm{T}_{8} \quad(100$ per cent $\mathrm{K}$ by vermicompost), $\mathrm{T}_{5}$ (50 per cent $\mathrm{RDK}+50$ per cent $\mathrm{K}$ by Azolla) and $\mathrm{T}_{6}(50$ per cent RDK + 50 per cent $\mathrm{K}$ by vermicompost). It is obvious from the data that addition of organic manure could increase the cation exchange capacity (CEC) of soil or organic colloids, which could hold more exchangeable $\mathrm{K}$ or probably caused greater adsorption of $\mathrm{K}$ from soil solution or convert $\mathrm{K}$ from non-exchangeable form to exchangeable form, consequent to mass action effect. Application of organic manure might have resulted in formation of metallo-organic complexes of high solubility. Further, the decomposition of organic matter from organic material produces organic acids, which might have caused the dissolution of non-exchangeable $\mathrm{K}$ and converting them into available forms. This supports the data obtained on the decrease in non-exchangeable $\mathrm{K}$ in the treatment receiving organic materials. The result obtained in trend of exchangeable $\mathrm{K}$ in soil on addition of Azolla and vermicompost as $\mathrm{K}$ sources was coherent with the results obtained by Dhanorkar et al., (1994), Kaur and Benipal (2006), Bhattacharya et al., (2008) and Venkateswarlu et al., (2014) (Fig. 2).

\section{Available potassium}

Available potassium constitutes water soluble and exchangeable potassium. Thus, the factors that changes water soluble and exchangeable $\mathrm{K}$, too have effect on available $\mathrm{K}$ status of soil. Result showed that the release of potassium was lower in soil receiving no potassium in comparison to soil receiving potassium. There was an increase in available potassium from 0 to 35 days of incubation, whereas, decreases thereafter up to 105 days of incubation but, the decrease in available $\mathrm{K}$ from 90 to 105 DAI was 13.87 per cent in $\mathrm{T}_{3}$ (100 per cent RDK), whereas, 3.97 per cent and 1.50 per cent decrease in treatment $\mathrm{T}_{5}(50$ per cent $\mathrm{K}$ by Azolla +50 per cent RDK) and $\mathrm{T}_{6}(50$ per cent $\mathrm{K}$ by $\mathrm{VC}+$ 50 per cent $\mathrm{RDK}$ ) respectively.

Results suggest that inclusion of organic material maintains considerable amount of available $\mathrm{K}$ for longer period of time and depletes at slower rate in comparison to treatments receiving only fertilizer K. Azolla and vermicompost is not only a source of $\mathrm{K}$ availability but also increases cation exchange capacity of soil by increasing organic surface capable of ion exchange, resulting in an increase in exchangeable and plant available K (Blake et al., 1999).

Lal et al., (2000) reported that with the increase in incubation time the $\mathrm{K}$ mineralized increased significantly and raised the available $\mathrm{K}$ pool in soil due to release of more organically bound potassium in course of decomposition of organic waste (Bear, 1976). Dhanorkar et al., (1994) observed that increase in available $\mathrm{K}$ was not only due to enrichment of $\mathrm{K}$ by organic material application. Besides this, native $\mathrm{K}$ also become more available due to action of organic acids liberated during decomposition of organic matter (Table 1 and Fig. 3). 
Table.1 Effect of Azolla, vermicompost and MOP on potassium fractions $\left(\mathrm{mg} \mathrm{kg}^{-1}\right)$ of incubated soil $(0-15 \mathrm{~cm}$ depth) at different days of incubation

\begin{tabular}{|c|c|c|c|c|c|c|c|c|c|c|c|c|c|c|c|c|c|c|c|c|}
\hline \multirow[b]{3}{*}{ 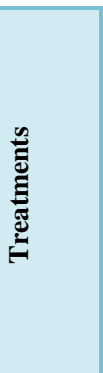 } & \multicolumn{20}{|c|}{ Incubation time (days) } \\
\hline & \multicolumn{5}{|c|}{ O DAI } & \multicolumn{5}{|c|}{35 DAI } & \multicolumn{5}{|c|}{70 DAI } & \multicolumn{5}{|c|}{105 DAI } \\
\hline & $\begin{array}{l}v \\
0 \\
0 \\
3 \\
0 \\
0 \\
0 \\
0 \\
3 \\
3\end{array}$ & $\begin{array}{l}\frac{v}{0} \\
\frac{0}{0} \\
\frac{\pi}{\pi} \\
\frac{\pi}{2}\end{array}$ & 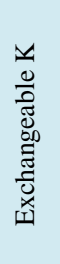 & 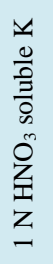 & 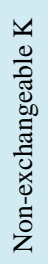 & 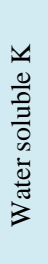 & $\begin{array}{l}\frac{y}{0} \\
\frac{0}{d \pi} \\
\frac{\pi}{\pi} \\
\frac{\pi}{2}\end{array}$ & 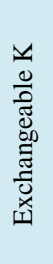 & 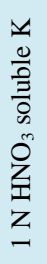 & 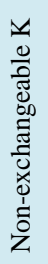 & $\begin{array}{l}y \\
0 \\
0 \\
0 \\
0 \\
0 \\
0 \\
\frac{0}{\pi} \\
3\end{array}$ & $\begin{array}{l}\frac{1}{0} \\
\frac{0}{0} \\
\frac{\pi}{\pi} \\
\frac{\pi}{2} \\
\frac{\pi}{4}\end{array}$ & 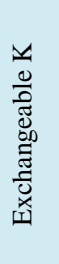 & 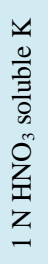 & 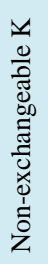 & 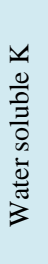 & $\begin{array}{l}\frac{v}{0} \\
\frac{0}{\pi} \\
\frac{\pi}{\pi} \\
\frac{\pi}{4}\end{array}$ & 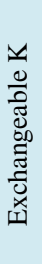 & 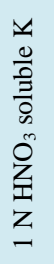 & 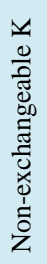 \\
\hline 音已 & 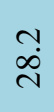 & $\begin{array}{l}0 \\
\infty\end{array}$ & 官 & $\stackrel{0}{\substack{\infty \\
m}}$ & $\begin{array}{l}\text { ڤે } \\
\text { ลे }\end{array}$ & กุ & $\stackrel{a}{\infty}$ & $\hat{\wp}$ & $\frac{i}{7}$ & $\begin{array}{l}\infty \\
\text { ஸें } \\
\text { ले }\end{array}$ & $\underset{\infty}{\infty}$ & $\stackrel{n}{\infty}$ & $\frac{n}{n}$ & $\hat{\vartheta}$ & $\frac{m}{m}$ & $\stackrel{\infty}{N}$ & $\frac{\sim}{\infty}$ & $\stackrel{\nabla}{\dot{n}}$ & $\begin{array}{l}\stackrel{0}{9} \\
\frac{9}{m}\end{array}$ & $\stackrel{\infty}{\stackrel{\alpha}{人}}$ \\
\hline 光 & $\stackrel{0}{\vec{\gamma}}$ & ஜ̊ & $\stackrel{n}{n}$ & \begin{tabular}{l}
0 \\
$\qquad$ \\
\multirow{+}{*}{}
\end{tabular} & ñ & $\frac{0}{i n}$ & กี & $\begin{array}{l}\forall \\
\ddot{6}\end{array}$ & ì & 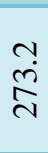 & in & さ & $\underset{\nabla}{\forall}$ & $\begin{array}{c}0 \\
\infty \\
\infty\end{array}$ & $\begin{array}{l}\hat{0} \\
\text { }\end{array}$ & ma & $\underline{0}$ & $\begin{array}{l}0 \\
\text { î }\end{array}$ & ㅎํ & ํ. \\
\hline 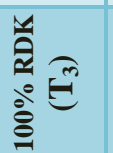 & $\frac{n}{7}$ & $\stackrel{\infty}{8}$ & $\stackrel{m}{n}$ & $\begin{array}{l}m \\
\infty \\
\wp\end{array}$ & $\begin{array}{l}0 \\
\text { ñ } \\
m\end{array}$ & $\begin{array}{l}0 \\
\dot{\infty}\end{array}$ & $\stackrel{\check{2}}{\check{2}}$ & $\underset{\sim}{\stackrel{\nabla}{\circ}}$ & $\stackrel{?}{\stackrel{?}{+}}$ & $\stackrel{m}{\stackrel{+}{d}}$ & $\stackrel{n}{\dot{d}}$ & $\stackrel{0}{\stackrel{0}{I}}$ & $\underset{\sim}{\stackrel{+}{\sim}}$ & @̊ & $\begin{array}{l}\forall \\
\stackrel{\nabla}{0}\end{array}$ & $\stackrel{n}{2}$ & $\begin{array}{l}0 \\
\stackrel{g}{ \pm}\end{array}$ & $\begin{array}{l}0 \\
i \\
\end{array}$ & \begin{tabular}{l}
$m$ \\
$\infty$ \\
\multirow{2}{*}{}
\end{tabular} & $\begin{array}{l}+ \\
\stackrel{+}{2}\end{array}$ \\
\hline 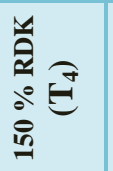 & 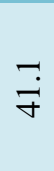 & $\stackrel{+}{\text { ¿̊ }}$ & $\frac{n}{6}$ & $\begin{array}{l}\text { ?ִ } \\
\text { ț }\end{array}$ & $\begin{array}{l}0 \\
\text { î } \\
\text { m }\end{array}$ & 동 & $\begin{array}{l}n \\
\infty \\
\infty\end{array}$ & $\stackrel{\infty}{\infty}$ & \begin{tabular}{l}
0 \\
\multirow{6}{0}{} \\
$\dot{1}$
\end{tabular} & $\frac{n}{2}$ & $\stackrel{\check{J}}{\sigma}$ & $\stackrel{\sim}{\infty}$ & $\underset{\infty}{\infty}$ & 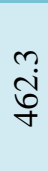 & $\begin{array}{l}0 \\
\stackrel{0}{0} \\
\infty\end{array}$ & ڤे & å & $\begin{array}{l}0 \\
i\end{array}$ & $\begin{array}{l}\stackrel{0}{\dot{P}} \\
\stackrel{y}{+}\end{array}$ & ڤn \\
\hline 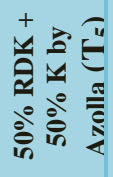 & $\frac{\sim}{\sim}$ & $\stackrel{m}{\infty}$ & $\vec{a}$ & $\stackrel{0}{\stackrel{\oplus}{\dot{f}}}$ & กิ่ & $\stackrel{\sim}{\infty}$ & in & மூ & $\begin{array}{l}0 \\
\mathfrak{\gamma} \\
\hat{q}\end{array}$ & $\begin{array}{l}\text { ले } \\
\text { ले }\end{array}$ & $\underset{\infty}{\infty}$ & $\begin{array}{l}\text { ڤ̊ } \\
\stackrel{n}{n}\end{array}$ & $\stackrel{n}{\curvearrowright}$ & $\frac{n}{n}$ & $\begin{array}{l}\text { ○ } \\
\text { ते }\end{array}$ & $\stackrel{+}{\stackrel{0}{\circ}}$ & ஜீ & $\stackrel{1}{\circ}$ & 守 & ๙ุ \\
\hline 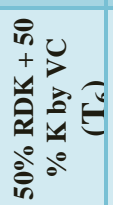 & $\underline{a}$ & $\stackrel{0}{\infty}$ & $\ddot{8}$ & $\begin{array}{r}\tilde{g} \\
\ddot{y}\end{array}$ & $\begin{array}{l}+ \\
\stackrel{+}{n}\end{array}$ & $\stackrel{m}{\mathbb{Z}}$ & $\stackrel{0}{\stackrel{d}{ \pm}}$ & $\stackrel{\sim}{ \pm}$ & †. & $\begin{array}{l}0 \\
\text { ஸे } \\
\text { mे }\end{array}$ & $\rightleftarrows$ & $\begin{array}{l}0 \\
\dot{0} \\
\pm\end{array}$ & $\ddot{n}$ & $\begin{array}{l}m \\
\stackrel{n}{f}\end{array}$ & $\stackrel{\infty}{\dot{0}}$ & ஜ) & $\stackrel{+}{\stackrel{\Xi}{ \pm}}$ & $\stackrel{\triangleright}{\infty}$ & $\begin{array}{l}\hat{b} \\
\dot{y}\end{array}$ & ָָ' \\
\hline
\end{tabular}




\begin{tabular}{|c|c|c|c|c|c|c|c|c|c|c|c|c|c|c|c|c|c|c|c|c|}
\hline 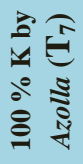 & $\stackrel{n}{\infty}$ & $\begin{array}{l}\infty \\
\infty \\
\infty\end{array}$ & $\ddot{8}$ & 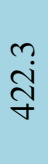 & ले & $\begin{array}{l}n \\
\infty \\
n\end{array}$ & $\begin{array}{l}\text { ạ } \\
\text { I }\end{array}$ & ஜ் & $\begin{array}{l}\circ \\
\stackrel{\sim}{+} \\
\dot{f}\end{array}$ & 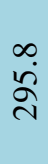 & $\vec{\infty}$ & $\stackrel{\infty}{n}$ & ๙ે & $\begin{array}{l}0 \\
\dot{0} \\
\dot{f}\end{array}$ & ণั & †े & $\stackrel{\stackrel{N}{ \pm}}{ \pm}$ & ñ & $\begin{array}{l}\text { å } \\
\text { }\end{array}$ & $\begin{array}{l}\vec{n} \\
\text { ڤे }\end{array}$ \\
\hline 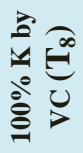 & 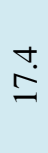 & $\frac{9}{6}$ & $\stackrel{n}{n}$ & $\frac{O}{\dot{+}}$ & $\begin{array}{l}\vec{b} \\
\stackrel{+}{0}\end{array}$ & $\begin{array}{l}n \\
n \\
n\end{array}$ & $\begin{array}{l}\stackrel{0}{~} \\
\stackrel{\sim}{\Xi}\end{array}$ & $\vec{\infty}$ & $\begin{array}{r}\dot{f} \\
\dot{f}\end{array}$ & $\begin{array}{l}\vec{\infty} \\
\stackrel{\sim}{\Omega}\end{array}$ & $\begin{array}{l}\infty \\
\text { in } \\
\text { in }\end{array}$ & $\begin{array}{l}n \\
\stackrel{J}{I}\end{array}$ & i. & $\stackrel{f}{f}$ & $\frac{N}{\infty}$ & $\stackrel{g}{\dot{f}}$ & $\begin{array}{l}\text { ?ִ } \\
\stackrel{9}{ \pm}\end{array}$ & $\begin{array}{l}\dot{v} \\
\check{\sigma}\end{array}$ & $\begin{array}{l}m \\
\stackrel{n}{\sigma} \\
\stackrel{\sigma}{\sigma}\end{array}$ & $\begin{array}{l}\text { ○े } \\
\text { ๙े }\end{array}$ \\
\hline$\underset{\Xi}{ \pm 1}$ & $\begin{array}{l}\stackrel{8}{0} \\
\stackrel{0}{0}\end{array}$ & $\exists$ & $\stackrel{\infty}{\infty}$ & $\begin{array}{l}\text { in } \\
\text { ¿ }\end{array}$ & $\begin{array}{l}\vec{J} \\
\text { i }\end{array}$ & $\underset{\dot{0}}{\stackrel{t}{0}}$ & రㅜ. & $\begin{array}{l}\text { రु } \\
\stackrel{0}{0}\end{array}$ & $\stackrel{m}{r}$ & $\frac{\circ}{i}$ & ڤ̊? & $\begin{array}{l}\text { ڤ̊ } \\
\text { : }\end{array}$ & $\stackrel{n}{\circ}$ & $\begin{array}{l}\hat{\sigma} \\
\text { i }\end{array}$ & 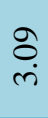 & $\underset{8}{8}$ & "ָ & $\begin{array}{l}\infty \\
\infty \\
0\end{array}$ & $\begin{array}{l}\hat{\sigma} \\
\text { तi }\end{array}$ & $\begin{array}{l}\circ \\
\infty \\
i\end{array}$ \\
\hline $\begin{array}{l}\text { ह̂. } \\
\stackrel{0}{0} \\
\text { II } \\
\text { है } \\
0\end{array}$ & 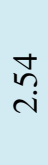 & $\begin{array}{l}\text { gे } \\
\dot{\sigma}\end{array}$ & $\stackrel{n}{n}$ & $\stackrel{n}{\stackrel{2}{0}}$ & กิ & $\frac{ \pm}{\dot{m}}$ & & $\begin{array}{l}\text { Jे } \\
\text { त }\end{array}$ & n? & $\stackrel{尺}{\stackrel{ }{\beth}}$ & $=$ & $\begin{array}{l}\infty \\
\stackrel{0}{+}\end{array}$ & 둠. & $\stackrel{N}{\stackrel{n}{=}}$ & $\stackrel{\sim}{\stackrel{\sim}{-}}$ & 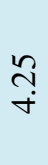 & $\begin{array}{l}\hat{b} \\
\dot{n}\end{array}$ & $\vec{\nabla}$ & $\stackrel{\text { nै }}{=}$ & $\frac{\Xi}{\sim}$ \\
\hline
\end{tabular}

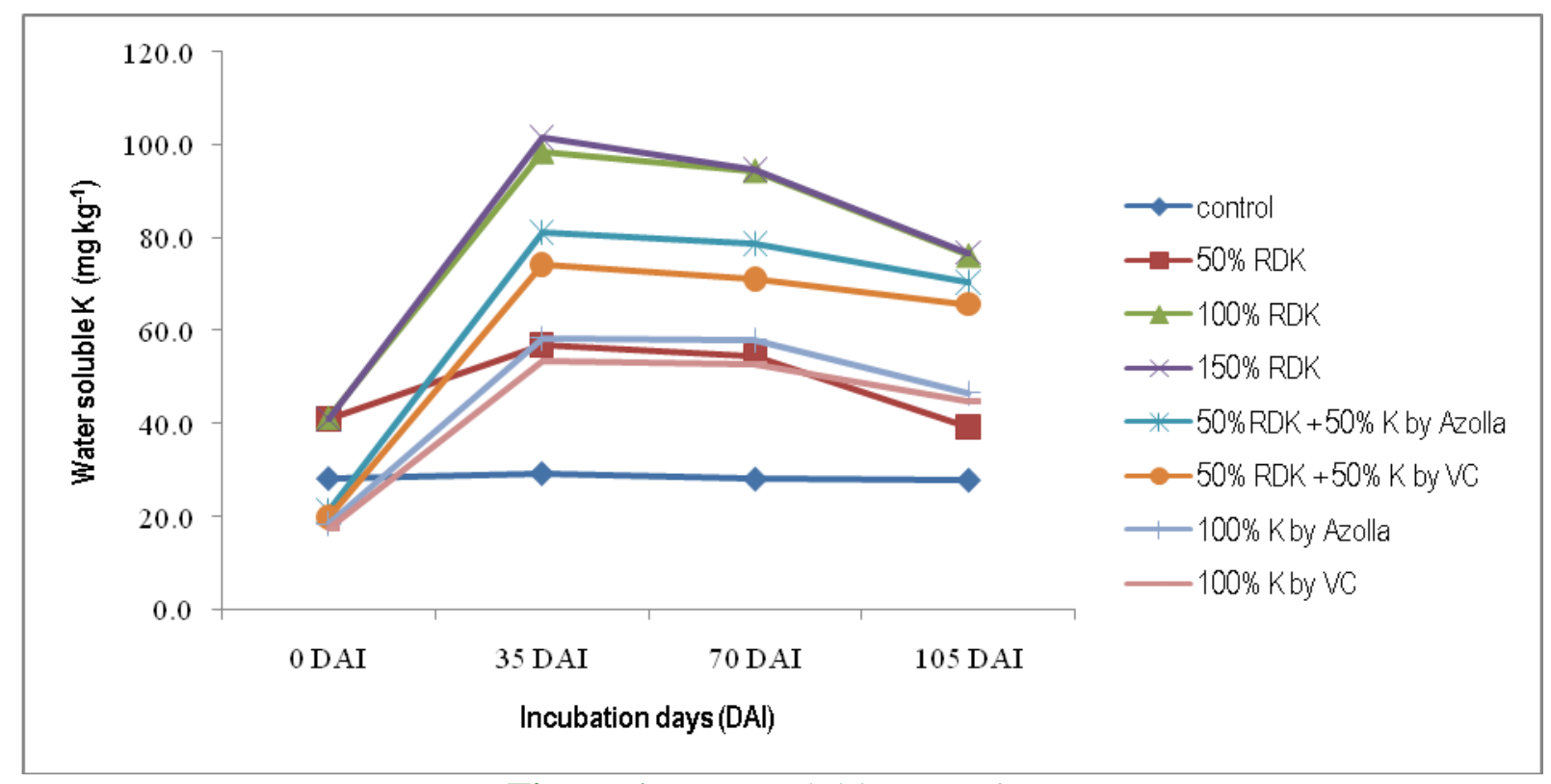

Figure.1 Water soluble potassium 


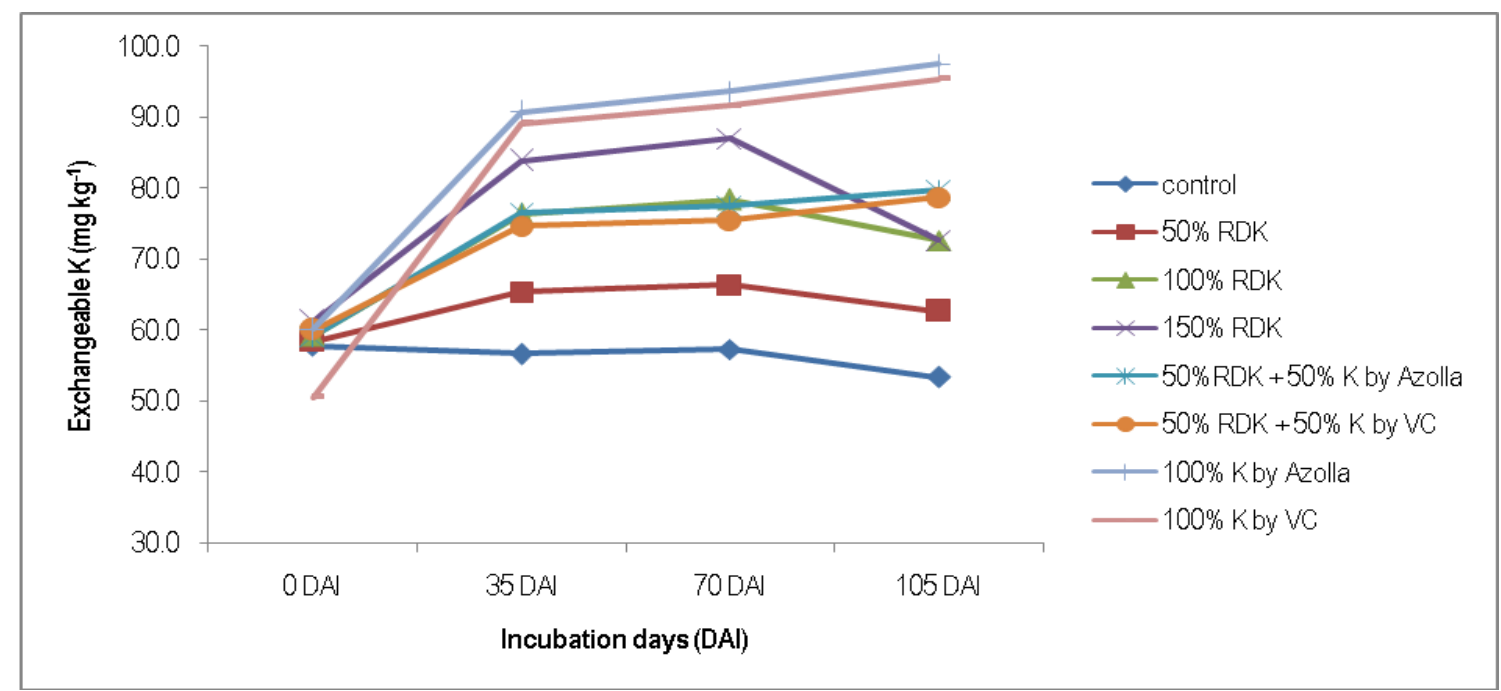

Figure.2 Exchangeable potassium

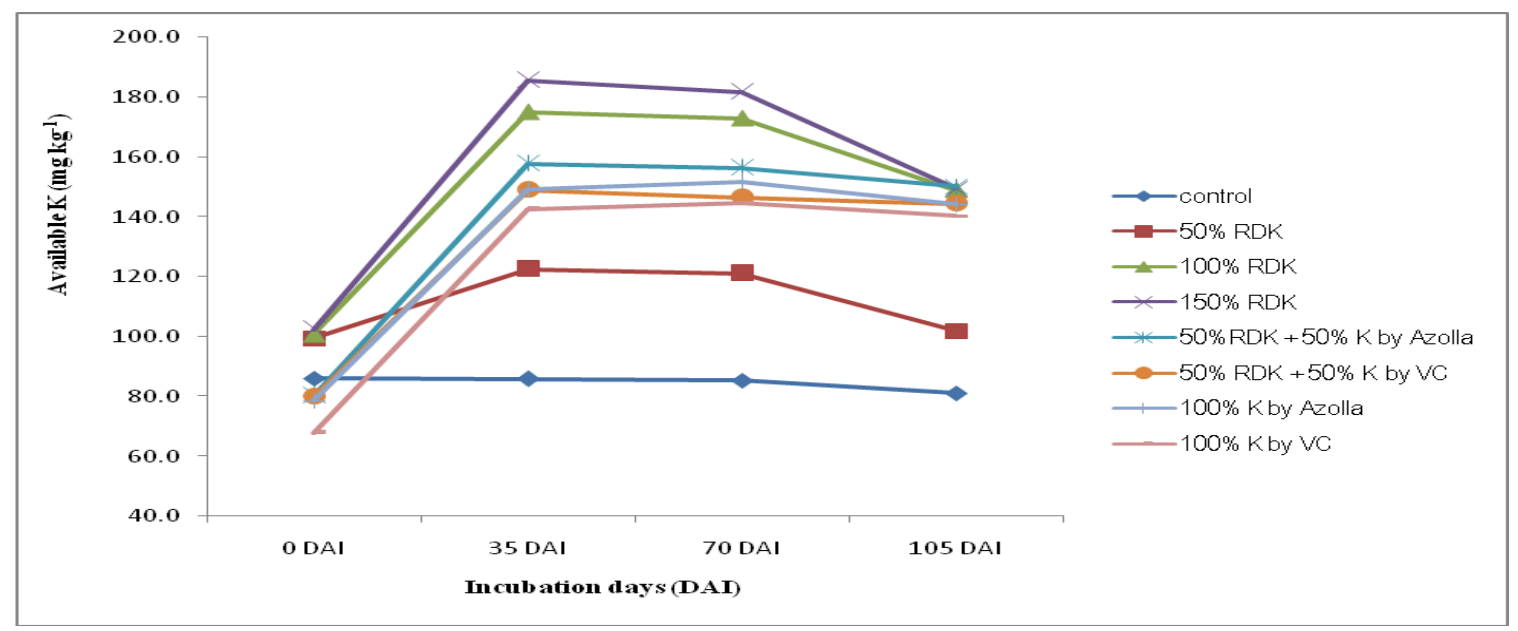

Figure.3 Available potassium

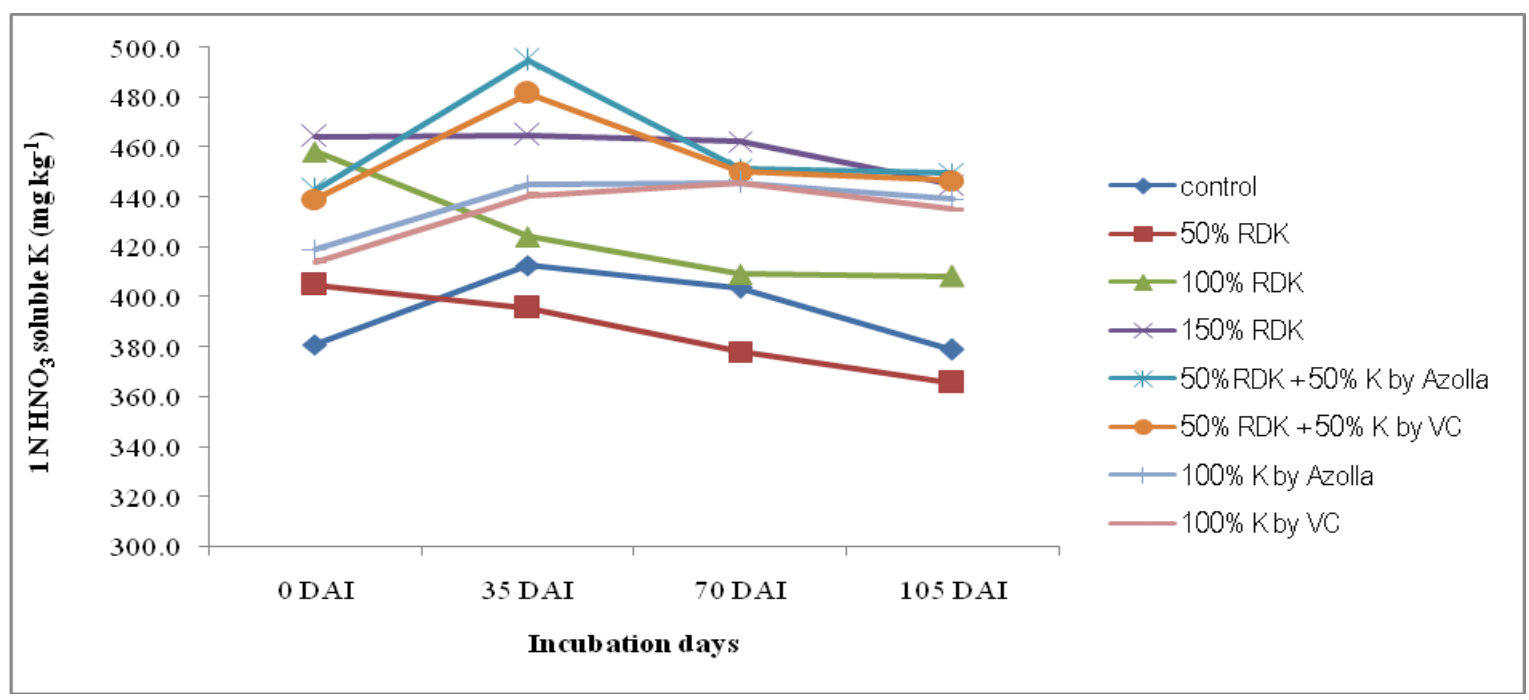

Figure.4 $1 \mathrm{~N}$ nitric acid soluble potassium 


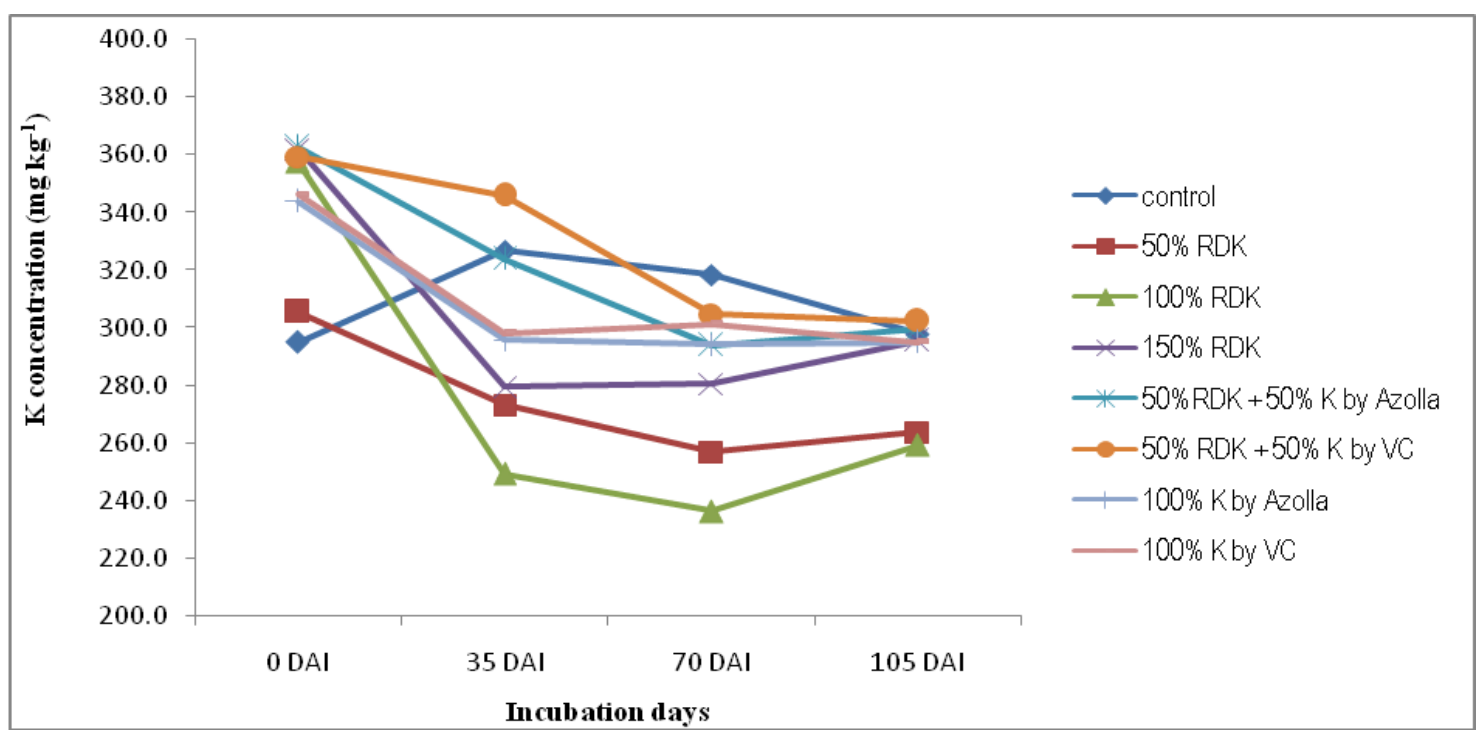

Figure.5 Non-exchangeable potassium

Brar et al., (1998) also reported increased availability of $\mathrm{K}$ content in manured soil than unmanured soil. The result obtained on availability of $\mathrm{K}$ under incubation study was similar to findings of Kaur and Benipal (2006).

\section{Nitric acid soluble potassium}

The result trend showed that at 35 days of incubation, fertilizer- $\mathrm{K}$ treated soil reported decrease in nitric acid soluble potassium, but reversed trend was observed in case of treatment receiving integrated or organic $\mathrm{K}$ application. However, after 35 days of incubation, integrated or organic $\mathrm{K}$ applied soil too showed decrease in $1 \mathrm{~N}^{\mathrm{HNO}_{3}}$ soluble $\mathrm{K}$ up to 70 days of incubation.

The decrease in nitric acid soluble $\mathrm{K}$ from 35 to 70 days of incubation by inclusion of organic material might be due to fact that organics increases CEC of soil, which hold more exchangeable $\mathrm{K}$ by mass action (Black, 1968). Similar results have been reported by Kaur and Benipal (2006) on studying all the forms of $\mathrm{K}$ in differentially $\mathrm{K}$ treated soil with inclusion of organic material under incubation study (Fig. 4).

\section{Non-exchangeable potassium or fixed potassium}

Result shows that at 0 days, variable amount of fixed $\mathrm{K}$ was observed, which might be due to changes in available $\mathrm{K}$ at 0 days owing to different $\mathrm{K}$ content of sources of potassium. This trend was more observable in treatment receiving fertilizer- K. However, at 35 days of incubation, control treatment shows increase in non-exchangeable $\mathrm{K}$ as well as in $\mathrm{T}_{6}(50$ per cent $\mathrm{RDK}+50$ per cent $\mathrm{K}$ by vermicompost) (Fig. 5).

While, rest of the treatment shows decreasing non-exchangeable $\mathrm{K}$ values and this supports the data of increasing trend of water soluble and exchangeable $\mathrm{K}$ at 35 days of incubation. After 35 days of incubation, integrated $\mathrm{K}$ application shows marked decrease in nonexchangeable $\mathrm{K}$ up to 70 days of incubation and then maintain a constant value up to 105 days of incubation. Whereas, treatment receiving $\mathrm{K}$ through either Azolla or VC application, was able to maintain fixed $\mathrm{K}$, inspite of increase in available $\mathrm{K}$. The result suggest that organic manure treated soil have more sustainability in respect of potassium balance in soil. 
The greater depletion of non-exchangeable $\mathrm{K}$ in integrated $\mathrm{K}$ application of potassium may be attributed to fact that there would be shift in the CEC sites towards divalent selectivity. The result was in agreement with the findings of Kaur and Benipal (2006).

The study indicated that application of Azolla and vermicompost alone or in combination with fertilizer ensure availability of potassium nutrient at 35, 70 and 105 DAI, i.e. during peak stages of crop growth. The decrease in available $\mathrm{K}$ from 90 to $105 \mathrm{DAI}$ was 13.87 per cent in $\mathrm{T}_{3}(100 \% \mathrm{RDK})$, while only 3.97 and 1.50 per cent decrease in treatment $\mathrm{T}_{5}(50$ $\% \mathrm{RDK}+50 \% \mathrm{~K}$ by Azolla $)$ and $\mathrm{T}_{6}(50 \%$ $\mathrm{RDK}+50 \% \mathrm{~K}$ by $\mathrm{VC}$ ) respectively. Thus, it is the need of the hour to focus on organic sources of nutrients for sustainable agriculture and environment.

\section{Acknowledgement}

The authors gratefully acknowledge the Department of Soil Science and Agricultural chemistry, Bihar Agricultural University, Sabour, Bhagalpur, Bihar, India to carry out this research work.

\section{References}

Bear, P. E., 1976. Chemistry of soil. Pp 280. Second Edn Oxford and IBH publishing Co. New Delhi.

Bhattacharyya, R., Prakash, V., Kundu, S., Ghosh, B. N. and Gupta, H. S. 2008. Potassium availability as influenced by farmyard manure application under continuous soybean-wheat cropping in a Typic Haplaquept. J. Ind. Soc. Soil Sci. 56(2): 182-85.

Blake, L., Mercik, S., Koerschens, M., Goulding, K.W.T., Stempen, S., Weigel, A., Poulton, P.R. and Powlson, D.S. 1999. Potassium content in soil, uptake in plants and the potassium balance in three European long-term field experiments. Plant and Soil. 216(1-2): 1-14.

Brar, B.S. and Pasricha, N.S. 1998. Longterm studies on integrated use of organic and inorganic fertilizers in maize-wheat-cowpea cropping system on alluvial soil of Punjab. In Proceedings of national workshop on long-term soil fertility management through integrated plant nutrient supply (pp. 154-168).

Dhanorkar B.A., Borkar D.K., Puranik R.B. and Joshi R.P. 1994. Forms of soil potassium as influenced by long-term application of FYM and NPK in vertisol. J. Pot. Res. 10:42-48.

Hanway, J.J. and Heidel, H. 1952. Soil analysis methods as used in Iowa State College, Soil Testing Laboratory, Iowa State College Bulletin. 57: 1-131.

Kaur, N. and Benipal, D. S. 2006. Effect of crop residue and farmyard manure on $\mathrm{K}$ forms on soils of long term fertility experiment. Indian J. Crop Science. 1: 161-164.

Keen, B.A. and H. Raczkowski, 1921. Relation between them clay content and certain physical properties of a soil. Journal of Agricultural Sci. 11: 441449.

Lal, J. K., Mishra, B. and Sarkar, A. K. 2000. Effect of Plant Residues incorporation on specific microbial groups and availability of some plant nutrients in soil. J. Indian Soc. Soil Sci. 48: 67-71.

Mengel, K. 1985. Potassium movement within plants and its importance in assimilate transport. Potassium in agriculture, pp. 397-411.

Peoples, M. B., Herridge, D. F. and Ladha, J. K. 1995. Biological nitrogen fixation: An efficient source of nitrogen for sustainable agricultural production. Plant and Soil. 174: 3-28.

Srinivasarao, C., Kundu, S., 
Ramachandrappa, B. K., Reddy, S., Lal, R., Venkateswarlu, B., Sahrawat, K. L. and Naik, R. P. 2014. Potassium release characteristics, potassium balance, and fingermillet (Eleusine coracana G.) yield sustainability in a 27-year long experiment on an Alfisol in the semiarid tropical India. Plant and soil. 374(1-2): 315-330.

Venkateshwarlu, M., Ghosh S. K., Patra, P. K., Biplab Pal and Kiran Reddy, G. 2014. To study the effect of fertilizer and organic manure on dynamic changes of potassium under cropping sequence. International Journal of Applied Biology and Pharmaceutical Technology. Vol.5, Issue 1.

Wang, J. J., Harrell, D. L., and Bell, P. F. 2004. Potassium buffering characteristics of three soils low in exchangeable potassium. Soil Sci. Soc., of Am. J. 68: 654-661.

Wood, L. K. and De Turk, E. E. 1940. The absorption of potassium in soils in nonexchangeable forms. Proc. Soil Sci. Soc. Am. J. 5: 152-161.

\section{How to cite this article:}

Mukta Rani, Arun Kumar Jha, Bipin Bihari, Amarjeet Kumar and Ajeet Kumar. 2020. An Incubation Experiment to Study Potassium Fractions using Azolla, Vermicompost and Muriate of Potash as Potassium Sources in Inceptisol of Bihar. Int.J.Curr.Microbiol.App.Sci. 9(05): 2573-2582. doi: https://doi.org/10.20546/ijcmas.2020.905.294 